\title{
Perbandingan Sistem Peradilan Tata Usaha Negara dan Conseil d'etat sebagai Institusi Pengawas Tindakan Hukum Tata Usaha Negara
}

\author{
W. Riawan Tjandra \\ Fakultas Hukum Universitas Atma Jaya Yogyakarta \\ Jl. Mrican Baru No. 28 Yogyakarta \\ willyriawan@yahoo.com
}

\begin{abstract}
French State Administrative Court system and Indonesian State Administrative Court system basically have many similarities. The legal problem studied in this paper is related to the attempt to widely manage the judge proactivity principle in the State Administrative Court to attribute the advisory function of the State Administrative Court as a part of active dimensions of the preventive control of the State Administrative Court toward the state administrative staff before a State Administrative Decision is stipulated. The research method used to discuss the problem is the normative legal research using legal comparative approach. The result of the study concludes that there is a necessity to broaden the function of State Administrative Court in Indonesia to increase the quality of the state administrative decisions issued by the state administrative authorities.
\end{abstract}

Key words: State administrative court, advisory function, state administrative decision

\begin{abstract}
Abstrak
Sistem Peradilan Tata Usaha Negara Perancis pada hakikatnya memiliki banyak persamaan dengan Peradilan Tata Usaha Negara di Indonesia. Permasalahan hukum yang dibahas dalam tulisan ini terkait dengan upaya untuk mengatur secara lebih luas asas keaktifan hakim di Peradilan Tata Usaha Negara untuk mengatribusikan fungsi penasihatan Peradilan Tata Usaha Negara sebagai bagian dari dimensi aktif pengawasan preventif Peradilan Tata Usaha Negara terhadap pejabat tata usaha negara sebelum suatu Keputusan Tata Usaha Negara ditetapkan. Penelitian yang digunakan untuk membahas permasalahan tersebut adalah penelitian hukum normatif dengan pendekatan perbandingan hukum. Hasil penelitian menyimpulkan bahwa perlunya perluasan fungsi Peradilan Tata Usaha Negara dengan meletakkan fungsi penasihatan sebagai bagian dari sistem Peradilan Tata Usaha Negara di Indonesia guna meningkatkan kualitas keputusan-keputusan tata usaha negara yang dikeluarkan oleh pejabat tata usaha negara.
\end{abstract}

Kata kunci: Peradilan tata usaha negara, fungsi penasihatan, keputusan tata usaha negara 


\section{Pendahuluan}

Sistem Peradilan Tata Usaha Negara bertujuan untuk melaksanakan fungsi pengawasan yudisial terhadap tindakan hukum tata usaha negara yang pelaksanaan fungsinya didasarkan antara lain atas asas keaktifan hakim dan asas pembuktian bebas. Asas keaktifan hakim secara prinsip memberikan kewenangan yang luas kepada Hakim Tata Usaha Negara dalam proses pemeriksaan sengketa tata usaha negara menyangkut pembagian beban pembuktian dan penentuan hal-hal yang harus dibuktikan. Konsekuensi dari keberadaan asas keaktifan hakim adalah dimungkinkannya penerapan asas ultra petita yang pertama kali dituangkan dalam putusan MA No. 5 K/TUN/1992, yaitu tindakan hakim menyempurnakan atau melengkapi objek sengketa yang diajukan para pihak kepadanya. ${ }^{1}$

Hakim administrasi diberikan peran aktif karena hakim tidak mungkin membiarkan dan mempertahankan tetap berlakunya suatu keputusan administrasi negara yang nyata keliru dan jelas bertentangan dengan undang-undang yang berlaku, hanya karena alasan para pihak tidak mempersoalkannya dalam objek sengketa. ${ }^{2}$ Asas keaktifan hakim (dominus litis) merupakan salah satu asas yang mendasari dan mencerminkan karakter spesifik dari Hukum Acara Peradilan Tata Usaha Negara. Dalam UU Peradilan Tata Usaha Negara Negara (UU No. 5 Tahun 1986 jo UU No. 9 Tahun 2004 dan UU No. 51 Tahun 2009) wujud penerapan asas keaktifan hakim terlihat dari rumusan Pasal 107 PTUN yang menyatakan bahwa: "Hakim menentukan apa yang harus dibuktikan, beban pembuktian beserta penilaian pembuktian, dan untuk sahnya pembuktian diperlukan sekurangkurangnya dua alat bukti berdasarkan keyakinan hakim."

Penjelasan Pasal 107 UU No. 5 Tahun 1986 berkaitan dengan keaktifan hakim tersebut menyatakan bahwa:

Berbeda dengan sistem hukum pembuktian dalam Hukum Acara Perdata, maka dengan memperhatikan segala sesuatu yang terjadi dalam pemeriksaan tanpa bergantung pada fakta dan hal yang diajukan oleh para pihak, hakim Peradilan Tata Usaha Negara dapat menentukan sendiri: a) apa yang harus dibuktikan; b) siapa yang harus dibebani pembuktian, hal apa yang harus dibuktikan oleh pihak yang berperkara dan hal apa saja yang harus dibuktikan oleh hakim sendiri; c) alat bukti mana saja yang diutamakan untuk dipergunakan dalam pembuktian; d) kekuatan pembuktian bukti yang telah diajukan.

\footnotetext{
${ }^{1}$ Marbun, Peradilan Administrasi Negara dan Upaya Adminstratif di Indonesia, Liberty, Yogyakarta, 1997, hlm. 303. ${ }^{2}$ Ibid.
} 
Berdasarkan asas keaktifan hakim tersebut sistem pengujian Keputusan Tata Usaha Negara di Peradilan Tata Usaha Negara Indonesia tersentralisasi di tangan Hakim Tata Usaha Negara, karena hakim diberikan kewenangan yang luas untuk menentukan objek yang harus dibuktikan, subjek (pihak) yang dibebani kewajiban pembuktian dan menilai pembuktian yang dilakukan. Diterapkannya asas pembuktian bebas berdasarkan ajaran pembuktian bebas (vrije bewijsleer) telah menempatkan hakim sebagai pusat dalam persidangan di PTUN. Eksistensi asas keaktifan hakim sebenarnya merupakan konsekuensi logis dari sifat sengketa tata usaha negara yang merupakan sengketa hukum publik antara pemerintah (bestuur) selaku penguasa (overheid) dengan rakyat (burger) selaku yang diatur (geregerd), sebagai akibat Keputusan Tata Usaha Negara (beschikking) yang dikeluarkan pemerintah. ${ }^{3}$

Diterapkannya asas keaktifan hakim tersebut telah menjadikan hakim harus berperan aktif sejak dimulainya rapat permusyawaratan dan pemeriksaan persiapan sebagai bagian dari pemeriksaan pendahuluan (preliminary examination), pelaksanaan persidangan, putusan dan pelaksanaan putusan pengadilan. Dalam pemeriksaan pendahuluan tersebut, Hakim Tata Usaha Negara menilai kelayakan surat gugatan sebagai titik tolak dimulainya pemeriksaan dalam persidangan di Peradilan Tata Usaha Negara Indonesia. Dalam persidangan, Hakim Tata Usaha Negara berperan aktif untuk mengarahkan jalannya persidangan dan dalam pembuktian melalui asas pembuktian bebas hakim mengkonstruksi struktur proses pembuktian yang dilaksanakan agar dapat diarahkan untuk mewujudkan kebenaran materiil (materiele waarheid).

Sistem pemeriksaan di Peradilan Tata Usaha Negara mencakup: dasar gugatan yang menjadi parameter untuk mengukur legalitas Keputusan Tata Usaha Negara (beschikking) sebagai objek sengketa tata usaha negara, metode pembuktian dan langkah-langkah menarik konklusi hukum atas dasar proses pembuktian yang telah dilaksanakan. Pengaruh asas keaktifan hakim dalam pengujian Keputusan Tata Usaha Negara berwujud metode khas dalam sistem Peradilan Tata Usaha Negara untuk mendeduksikan teori-teori hukum administrasi negara dan norma-norma Hukum Administrasi Negara yang bersifat umum maupun sektoral untuk menilai legalitas suatu Keputusan Tata Usaha Negara yang disengketakan secara hukum oleh para pihak di Peradilan Tata Usaha Negara. hlm. 118.

${ }^{3}$ W. Riawan Tjandra, Teori dan Praktik Peradilan Tata Usaha Negara, Cahaya Atma Pustaka, Yogyakarta, 2011, 


\section{Rumusan Masalah}

Adapun permasalahan dalam penelitian ini adalah bagaimana perluasan asas keaktifan hakim yang dimiliki oleh hakim di Peradilan Tata Usaha Negara Indonesia dan Conseil d'etat untuk mengatribusikan fungsi penasihatan Peradilan Tata Usaha Negara sebagai bagian dari dimensi aktif pengawasan preventif Peradilan Tata Usaha Negara terhadap pejabat tata usaha negara sebelum suatu Keputusan Tata Usaha Negara ditetapkan?

\section{Tujuan Penelitian}

Penelitian ini dimaksudkan untuk mengetahui dan menganalisis perluasan asas keaktifan hakim yang dimiliki oleh hakim di Peradilan Tata Usaha Negara dan Conseil d'etat untuk mengatribusikan fungsi penasihatan Peradilan Tata Usaha Negara sebagai bagian dari dimensi aktif pengawasan preventif Peradilan Tata Usaha Negara terhadap pejabat tata usaha negara sebelum suatu Keputusan Tata Usaha Negara ditetapkan.

\section{Metode Penelitian}

Metode yang digunakan untuk membahas permasalahan di atas adalah penelitian hukum normatif melalui pendekatan perbandingan hukum (comparative law). Istilah perbandingan hukum sendiri dapat didefinisikan sebagai studi sistematis mengenai bagian dari tradisi-tradisi dan aturan-aturan hukum berdasarkan suatu perbandingan. Guna mengkualifikasikan sesuatu sungguh-sungguh sebagai suatu perbandingan hukum, mempersyaratkan adanya dua atau lebih sistem-sistem hukum, atau dua atau lebih tradisi hukum (legal traditions) atau bagian-bagian tertentu, kelembagaan atau cabang-cabang dari dua atau lebih sistem-sistem hukum. ${ }^{4}$ Dari perbandingan tersebut dapat ditemukan unsur-unsur persamaan dan perbedaan kedua sistem hukum itu. ${ }^{5}$ Penelitian ini dilakukan melalui studi dokumen (documentary study) dengan cara mengkaji literatur-literatur dan peraturan perundangundangan yang mengatur sistem peradilan tata usaha negara di Perancis dan Indonesia guna menjawab permasalahan yang telah dikemukakan di atas.

\footnotetext{
${ }^{4}$ Peter de Cruz, Comparative Law in a Changing World, Second Edition, Cavendish Publishing Limited, Sidney, Australia, 1999, hlm. 3.

${ }^{5}$ Johnny Ibrahim, Teori dan Metodologi Penelitian Hukum Normatif, Bayumedia, Malang, 2006, hlm. 313.
} 


\section{Hasil Penelitian dan Pembahasan}

\section{Sistem Peradilan Tata Usaha Negara Perancis}

Kekhususan sistem Peradilan TUN di Perancis adalah adanya struktur organisasi Peradilan TUN yang berdiri sendiri dan terpisah dari peradilan umum, bahkan tidak termasuk dalam lingkungan kekuasaan yudikatif. Berkaitan dengan sistem peradilan di Perancis, Auby ${ }^{6}$ menyatakan bahwa sistem peradilan di Perancis memiliki dua sistem peradilan (dual system of courts), peradilan umum (ordinary courts/ the ordre judiciare) dan peradilan administrasi (administrative courts/ordre administratif). Peradilan umum dibagi dalam peradilan yang memiliki wewenang perdata dan wewenang pidana, kecuali jika melibatkan negara atau pejabat publik atau badan hukum publik sebagai pihak, dalam kasus tersebut Peradilan TUN memiliki wewenang khusus. Struktur Peradilan TUN di Perancis berpuncak pada Conseil d'etat, yang merupakan institusi seperti Dewan Pertimbangan Agung di Indonesia dalam UUD 1945 (naskah asli), tetapi dengan kewenangan yang amat luas baik di bidang administratif maupun peradilannya. Kesatuan yurisprudensi dalam Hukum Administrasi Negara di Perancis diperoleh melalui arrest-arrest atau putusan-putusan Conseil d'etat di bidang Peradilan TUN.

Di samping eksistensi Conseil d'etat sebagai puncaknya, daerah-daerah di Perancis juga terdapat lembaga Tribunal Administratif, yaitu Badan Peradilan Tata Usaha Negara yang memeriksa dan memutus sengketa Tata Usaha Negara di tingkat pertama. Putusan-putusan di tingkat Tribunal Administratif, yang di seluruh Perancis terdapat 25 Tribunal Administratif, dapat dimohonkan banding (appel) kepada Conseil d'etat yang berkedudukan hukum di Paris.

Conseil d'etat maupun Tribunal Administratif memiliki dua fungsi atau peranan ganda, yaitu sebagai lembaga penasihat pemerintah dan sekaligus sebagai lembaga peradilan tata usaha negara. Dengan demikian, dapat dikatakan bahwa fungsi pengawasan oleh Conseil d'etat maupun Tribunal Administratif bersifat preventif (penasihatan kepada pemerintah) dan represif (pengujian keputusan administratif). Sejak 1872 lembaga Conseil d'etat sungguh-sungguh menjalankan fungsi sebagai peradilan tata usaha negara dan melalui fungsionarisnya yang berposisi sungguh-

${ }^{6}$ Seerden, Rene dan Frits Stroink, Administrative Law of the European Union, its Member States and the United States, Intersentia Uitgevers Antwerpen, Groningen, Netherlands, 2002, hlm. 75. 
sungguh sebagai hakim tata usaha negara memiliki wewenang untuk mengeluarkan putusan peradilan tata usaha negara yang mengikat. Peradilan tersebut telah mengembangkan asas-asas dan peraturan-peraturan hukum yang melaluinya perbuatan-perbuatan tata usaha negara dilakukan pengujian. ${ }^{7}$

Selain dua lembaga Peradilan TUN di atas, di Perancis juga terdapat badanbadan Peradilan TUN yang bersifat khusus dengan kompetensi/wewenang di bidang-bidang tertentu atau terbatas pada materi-materi tertentu. Secara umum, lembaga-lembaga itu memiliki wewenang pemeriksaan di tingkat pertama dan banding (appel) sedangkan kasasinya dilakukan kepada Conseil d'etat. Wewenang badan peradilan khusus tersebut misalnya menyangkut masalah-masalah: 1) keuangan negara, yang diperiksa dan diputus oleh Cour des Comptes (semacam Badan Pengawas Keuangan); 2) pendidikan termasuk juga menyangkut persoalan universitas; 3) pajak; 4) jaminan sosial; 5) bidang jabatan profesional seperti: dokter, advokat, arsitek, dan lain-lain.

Sistem Peradilan TUN di Perancis yang terpisah sama sekali dari struktur organisasi peradilan umum, disebut sebagai sistem duality ofjurisdiction, yaitu adanya peradilan umum (jurisdiction judiciaire) di satu sisi, dan di sisi lain ada Peradilan TUN (jurisdiction administrative). A pabila terjadi sengketa yurisdiksi di antara institusi peradilan dalam satu sistem, maka masing-masing akan diselesaikan oleh puncak peradilan dari masing-masing sistem itu, yaitu untuk sengketa tata usaha negara akan diselesaikan oleh Conseil d'etat dan untuk sengketa di lingkungan peradilan umum akan diselesaikan oleh Cour de Cassation (Mahkamah Agung).

Apabila terjadi sengketa yurisdiksi antara badan peradilan umum dan badan Peradilan TUN, maka hal tersebut akan diperiksa dan diputus oleh suatu lembaga peradilan kolegial yang disebut dengan Tribunal des Conflicts. Tribunal des Conflicts tersebut terdiri dari 3 (tiga) orang hakim agung dari Cour de Cassation dan 3 (tiga) orang anggota Conseil d'etat, ditambah dengan 2 (dua) orang anggota pengganti yang masing-masing diambil dari Cour de Cassation dan Conseil d'etat.

${ }^{7}$ Sauveplanne, JG., Rechtsstelsels in Vogelvlucht - Een Inleiding tot de Privaatsrechtsvergelejiking, tweede druk, Kluwer-Deventer, 1981, hlm. 45 


\section{Tabel 1}

\section{Organisasi Peradilan di Perancis}

\begin{tabular}{|c|c|}
\hline \multicolumn{2}{|c|}{$\begin{array}{l}\text { Conseil Constitutioneel } \\
\text { (not connected to the rest of the apparatus: only the Preseident, the Government } \\
\text { and Members of Parliement can challenge statutes before the Conseil } \\
\text { Constitutioneel, not the courts, nor the citizens) }\end{array}$} \\
\hline \multicolumn{2}{|c|}{$\begin{array}{l}\text { Tribunal des Conflicts } \\
\text { (only in charge of dispatching cases between administrative and judiciary courts } \\
\text { when jurisdiction is debated) }\end{array}$} \\
\hline $\begin{array}{l}\text { Administrative Courts } \\
\text { (Jurisdictions administratives) }\end{array}$ & $\begin{array}{c}\text { Judiciary Courts } \\
\text { (jurisdictions judiciaries) }\end{array}$ \\
\hline $\begin{array}{l}\text { Conseil d'etat } \\
\text { Courts administratives d'appel } \\
\text { Tribunaux administratifs }\end{array}$ & $\begin{array}{l}\text { Cour de Cassation } \\
\text { Cours d'appel } \\
\text { Tribunaux de grande et tribunal d'instance (civil } \\
\text { courts), tribunaux de commerce (commercial } \\
\text { courts), conseils de prud'hommes (labour courts)... }\end{array}$ \\
\hline
\end{tabular}

Sumber: Seerden dan Stroink, 2002: 76

Proses beracara di Peradilan TUN Perancis secara prinsip tidak didasarkan atas suatu hukum acara yang dikodifikasikan dalam suatu kitab undang-undang hukum acara seperti halnya untuk perkara perdata dan pidana, demikian juga hukum materiil yang diterapkan tidak didasarkan atas Hukum Administrasi Negara yang dikodifikasikan seperti di Indonesia yang banyak dipengaruhi oleh sistem hukum administrsi di Belanda. Hal tersebut berimplikasi terhadap kuatnya peranan dan pengaruh yurisprudensi dalam sistem Peradilan TUN di Perancis.

Dasar pengajuan gugatan ke Peradilan TUN di Perancis pada umumnya dibedakan atas 2 (dua) macam sifat gugatan yaitu: ${ }^{8}$ a) gugatan yang dimaksudkan untuk memohonkan pembatalan suatu keputusan tata usaha negara (akta administratif), yang disebut sebagai gugatan pembatalan (recours en exces de pouvoir); b) gugatan yang disamping memohon pembatalan atas suatu produk keputusan tata usaha negara, juga menuntut pembayaran ganti rugi kepada pemerintah atas tindakan hukum pemerintah yang menimbulkan kerugian, yang disebut sebagai gugatan ganti rugi (recours en plein contentiuex).

Alasan atau dasar pengajuan permohonan pembatalan suatu keputusan tata usaha negara adalah bahwa akta administratif yang bersangkutan bersifat illegal

${ }^{8}$ Paulus Effendie Lotulung, Beberapa Sistem tentang Kontrol Segi Hukum terhadap Pemerintah Edisi ke-II, Penerbit Citra Aditya Bakti, Bandung, 1993, hlm. 5. 
atau tidak berdasarkan hukum. Dalam sistem Peradilan TUN di Perancis, illegalitas tersebut diklasifikasikan atas 2 (dua) kelompok, yaitu': 1) illegalitas ekstern, yang penilaiannya meliputi penilaian tentang syarat formal untuk sahnya suatu akta administratif (dari segi bentuk luarnya); 2) illegalitas intern, yang penilaiannya meliputi penilaian tentang syarat material untuk sahnya suatu akta administratif (dari segi substansi/isi akta administratif). Kedua alasan gugatan tersebut dapat dijelaskan berikut ini: pertama, Illegalitas ekstern. Alasan pembatalan yang didasarkan atas illegalitas ekstern meliputi: a) Tanpa kewenangan (kompetensi), yaitu akta administratif dikeluarkan oleh seorang pejabat tata usaha negara yang tidak mempunyai kompetensi (kewenangan) sama sekali untuk mengeluarkan akta administratif tersebut, atau kewenangan tersebut sesungguhnya ada pada pejabat yang lain $^{10}$. Kriteria tanpa kewenangan tersebut dapat diperinci lagi atas 3 (tiga) bentuk yaitu $^{11}$ : 1) tanpa kewenangan yang bersifat materiil, seorang pejabat yang mengeluarkan suatu akta administratif mengenai materi atau masalah yang secara substansi sebenarnya materi atau masalah itu menjadi wewenang dari pejabat lainnya; 2) tanpa kewenangan yang ditinjau dari segi wilayah atau tempat sehubungan dengan wilayah yurisdiksi seharusnya akta administratif itu dapat dikeluarkan; 3) tanpa kewenangan yang ditinjau dari segi waktu berlakunya atau dikeluarkannya suatu akta administratif yang menyimpang dari waktu yang seharusnya diperhatikan; b) kekeliruan bentuk dan prosedur. Suatu akta administratif dikeluarkan secara bertentangan dengan formalitas yang telah ditentukan sebelumnya dalam peraturan dasarnya atau telah terjadi penyimpangan dari prosedur yang seharusnya diikuti dalam penetapan. Kedua, Illegalitas Intern. Alasan pembatalan yang didasarkan atas kriteria ini meliputi: ${ }^{12}$ a) bertentangan dengan Undang-undang atau peraturan hukum lainnya; Alasan ini dipergunakan bila pejabat yang mengeluarkan keputusan administratif yang bersangkutan tidak memperhatikan atau tidak bertindak sesuai dengan Undang-undang atau peraturan hukum lainnya yang seharusnya menjadi dasar dikeluarkannya keputusan administratif yang bersangkutan; b) adanya penyalahgunaan kekuasaan (detournement de pouvoir). Alasan ini dipergunakan jika seorang pejabat dalam mengeluarkan keputusan administratif dengan sengaja mempergunakan wewenangnya untuk tujuan/maksud yang menyimpang dari

\footnotetext{
${ }^{9}$ Ibid., hlm. 7-8.

${ }^{10}$ Ibid.

${ }^{11}$ Ibid.

${ }^{12}$ Ibid.
} 
tujuan/maksud semula dari pemberian wewenang tersebut kepada pejabat yang bersangkutan.

Suatu keputusan administratif supaya dapat dinyatakan sah menurut Auby harus memenuhi unsur-unsur berikut: ${ }^{13}$ a) ada yang membuat: seseorang atau badan kolektif yang menetapkannya; b) memiliki bentuk tertentu dan ditetapkan melalui prosedur yang ditentukan; c) memiliki isi menyangkut pertanyaan: apa yang ditetapkan? Apa yang dinyatakan?; d) memiliki pertimbangan tertentu, alasan-alasan tertentu: ditetapkan berdasarkan fakta-fakta tertentu dan didasarkan atas pertimbangan-pertimbangan hukum tertentu; e) memiliki tujuan, satu atau beberapa tujuan: ditujukan untuk mencapai satu atau beberapa kemanfaatan tertentu.

Pola pengujian materiil di Perancis menurut Auby dilakukan sehubungan dengan beberapa dasar pengujian materiil berikut: ${ }^{14}$ a) ketidakwenangan (incompetence): keputusan tidak ditetapkan oleh seorang pejabat atau badan hukum publik yang memiliki wewenang untuk menetapkan; b) pelanggaran prosedur (vice de forme ou de procedure): keputusan administratif cacat mengenai bentuknya atau tidak mengikuti prosedur penetapan dalam menetapkannya; c) pelanggaran hukum (violation de la loi): substansi keputusan bertentangan dengan satu atau beberapa ketentuan yang harus diikuti oleh pejabat tata usaha negara; d) ketidaksahan pertimbangan (vices de motifs): dapat diperinci menjadi 3 (tiga) macam: kesalahan dalam fakta (erreur de fait), kesalahan menyangkut hukum (erreur de droit); ketidaktepatan dalam kualifikasi atau ketidaktepatan dalam mengkualifikasikan faktanya (erreur dans la qualification juridique des faits, erreur manifeste d'appreciation, et cetera).

Sehubungan dengan wewenang mengadili gugatan ganti rugi yang berkaitan dengan pertanggungjawaban negara untuk membayar ganti rugi, hal tersebut sebagian besar merupakan hasil perkembangan dari yurisprudensi Conseil d'etat, dan sebagian kecil dikembangkan melalui undang-undang. Guna menilai pertanggungjawaban negara untuk membayar ganti rugi, yurisprudensi di Perancis telah mengembangkan teori "kesalahan" yang pada prinsipnya membedakan antara kesalahan dinas (faute de service) dan kesalahan pribadi pejabat (faute personelle). Di samping itu, juga dilakukan klasifikasi lagi atas kesalahan berat (faute fourde) dan kesalahan ringan (faute legere). Pertanggungjawaban pemerintah untuk membayar ganti rugi juga telah mengalami perluasan melalui putusan Conseil d'etat, yang

\footnotetext{
${ }^{13}$ Seerden dan Stroink, Op.Cit., hlm. 83

${ }^{14}$ Ibid., hlm. 83-84.
} 
disebut dengan teori "responsibilite sans faute" (pertanggungjawaban tanpa kesalahan). Berdasarkan teori tersebut, sekalipun tidak terdapat unsur kesalahan/kelalaian pada pihak pemerintah/negara, tetapi pemerintah dapat pula dibebani dengan kwajiban untuk membayar ganti rugi kepada rakyat / warga negara yang menjadi korban pelaksanaan tugas administratif.

\section{Sistem Peradilan Tata Usaha Negara Indonesia}

Dasar pengajuan gugatan di Peradilan TUN Indonesia adalah Pasal 53 ayat (2) UU No. 5 Tahun 1986 yang kini direvisi melalui UU No. 9 Tahun 2004 dan UU No. 51

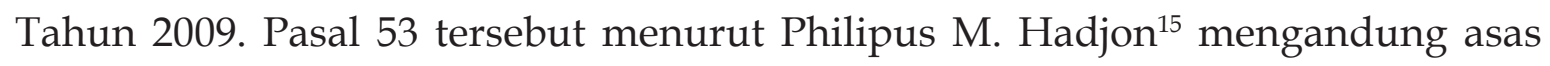
keabsahan dalam pemerintahan yang memiliki 3 (tiga) fungsi: a) bagi aparat pemerintahan, asas keabsahan berfungsi sebagai norma pemerintahan (bestuursnormen); b) bagi masyarakat, asas keabsahan berfungsi sebagai alasan mengajukan gugatan terhadap tindak pemerintahan (beroepsgronden); c) bagi hakim, asas keabsahan berfungsi sebagai dasar pengujian suatu tindak pemerintahan (toetsingsgronden).

Alasan pengajuan gugatan di Peradilan TUN menurut Pasal 53 ayat (2) UU No. 5 Tahun 1986 terdiri dari: a) Keputusan Tata Usaha Negara yang digugat itu bertentangan dengan peraturan perundang-undangan yang berlaku; b) badan atau Pejabat Tata Usaha Negara pada waktu mengeluarkan keputusan sebagaimana dimaksud dalam ayat (1) telah menggunakan wewenangnya untuk tujuan lain dari maksud diberikannya wewenang tersebut; c) badan atau Pejabat Tata Usaha Negara pada waktu mengeluarkan atau tidak mengeluarkan keputusan sebagaimana dimaksud dalam ayat (1) setelah mempertimbangkan semua kepentingan yang tersangkut dengan keputusan itu seharusnya tidak sampai pada pengambilan atau tidak pengambilan keputusan tersebut.

Alasan pengajuan gugatan sebagaimana dimaksud dalam Pasal 53 ayat (2) UU No. 5 Tahun 1986 kemudian direvisi melalui Pasal 53 ayat (2) UU No. 9 Tahun 2004 sehingga alasan pengajuan gugatan di Peradilan TUN terdiri dari: a) Keputusan Tata Usaha Negara yang digugat itu bertentangan dengan peraturan perundangundangan yang berlaku; b) Keputusan Tata Usaha Negara yang digugat itu bertentangan dengan asas-asas umum pemerintahan yang baik.

${ }^{15}$ Hadjon, PM.,Fungsi Normatif Hukum Administrasi dalam Mewujudkan Pemerintahan yang Bersih, Pidato diucapkan dalam peresmian penerimaan jabatan Guru Besar dalam Ilmu Hukum pada Fakultas Hukum Universitas Airlangga pada hari Senin tanggal 10 Oktober 1994. 
Mengenai alasan gugatan sebagaimana disebutkan pada Pasal 53 ayat (2) huruf a UU No. 9 Tahun 2004 di atas tidak ada penjelasan pada bagian penjelasan pasal tersebut elemen-elemen yang dapat dipergunakan untuk menjabarkan dasar pengujian yang diatur pada Pasal 53 ayat (2) huruf a “Keputusan Tata Usaha Negara yang digugat itu bertentangan dengan peraturan perundang-undangan yang berlaku". Jika menggunakan penafsiran historis, alasan-alasan untuk mengajukan gugatan yang pernah diatur dalam Pasal 53 ayat (2) UU No. 5 Tahun 1986 terdiri dari 3 (tiga) hal, yaitu: Pertama, Keputusan Tata Usaha Negara yang digugat itu bertentangan dengan peraturan perundang-undangan yang berlaku (Pasal 53 ayat (2) sub a). Suatu Keputusan Tata Usaha Negara dapat dinilai “bertentangan dengan peraturan perundang-undangan yang berlaku' apabila keputusan yang bersangkutan itu: 1) bertentangan dengan ketentuan-ketentuan dalam peraturan perundang--undangan yang bersifat prosedur/formal; 2) bertentangan dengan ketentuan-ketentuan dalam peraturan perundang-undangan yang bersifat materiil/ substansial; 3) dikeluarkan oleh Badan atau Pejabat Tata Usaha Negara yang tidak berwenang.

Keputusan Tata Usaha Negara yang dikeluarkan oleh Badan atau Pejabat TUN yang tidak berwenang (onvoegdheid) disebut keputusan yang cacat mengenai kewenangan (bevoegdheidsgebreken). yang meliputi: ${ }^{16}$ a) Onbevoegdheid ratione materiae, yaitu apabila suatu keputusan tidak ada dasarnya dalam peraturan perundangundangan atau apabila keputusan itu dikeluarkan oleh badan atau pejabat TUN yang tidak berwenang mengeluarkannya; b) Onbevoegdheid ratione loci, keputusan yang diambil oleh badan atau pejabat TUN tersebut menyangkut hal yang berada di luar batas wilayahnya (geografis); c) Onbevoegdheid ratione temporis, badan atau pejabat TUN belum berwenang atau tidak berwenang lagi untuk mengeluarkan keputusan TUN, misalnya karena jangka waktunya sudah lampau atau menerapkan peraturan lain sementara itu sudah berlaku peraturan baru. Kedua, Badan atau Pejabat Tata Usaha Negara pada waktu mengeluarkan keputusan sebagaimana dimaksud dalam Pasal 53 ayat (1) telah menggunakan wewenangnya untuk tujuan lain dari maksud diberikannya wewenang tersebut (Pasal 53 ayat (2b)). Dasar pembatalan ini sering disebut penyalahgunaan wewenang. Setiap penentuan normanorma hukum di dalam tiap peraturan itu tentu dengan tujuan dan maksud tertentu. Oleh karena itu, penerapan ketentuan tersebut harus selalu sesuai dengan tujuan

\footnotetext{
${ }^{16}$ Periksa Penjelasan Pasal 53 ayat (2) UU No. 5 Tahun 1986 tentang Peradilan Tata Usaha Negara.
} 
dan maksud khusus diadakannya peraturan yang bersangkutan. Peraturan yang bersangkutan tidak dibenarkan untuk diterapkan guna mencapai hal-hal yang terletak di luar maksud tersebut. Dengan begitu wewenang material Badan atau Pejabat TUN yang bersangkutan dalam mengeluarkan keputusan Tata Usaha Negara juga terbatas pada ruang lingkup maksud bidang khusus yang telah ditentukan dalam peraturan dasarnya. Ketiga, Badan atau Pejabat Tata Usaha Negara pada waktu mengeluarkan atau tidak mengeluarkan keputusan sebagaimana dimaksud dalam Pasal 53 ayat (1) setelah mempertimbangkan semua kepentingan yang tersangkut dengan keputusan itu seharusnya tidak sampai pada pengambilan atau tidak pengambilan ke-putusan tersebut (Pasal 53 ayat (2) sub c). Dasar pembatalan ini sering disebut larangan berbuat sewenang-wenang. Suatu peraturan dasar yang memberikan wewenang kepada Badan atau Pejabat Tata Usaha Negara adakalanya mengatur secara sangat terinci dan ketat apa yang harus dilaksanakan dan mengikat Badan atau Pejabat Tata Usaha Negara dalam melakukan urusan pemerintahan.

Berkaitan dengan alasan gugatan menurut Pasal 53 ayat (2) huruf b UU No. 9 Tahun 2004, Penjelasan Pasal 53 ayat (2) huruf b UU No. 9 Tahun 2004 menyatakan bahwa yang dimaksud dengan "asas-asas umum pemerintahan yang baik" adalah meliputi asas: kepastian hukum, tertib penyelenggaraan negara, keterbukaan, proporsionalitas, profesionalitas, dan akuntabilitas sebagaimana dimaksud dalam UU No. 28 Tahun 1999 tentang Penyelenggara Negara yang Bersih dan Bebas dari Korupsi, Kolusi dan Nepotisme (KKN).

Jika dasar pengajuan gugatan tersebut dibandingkan dengan di Perancis terdapat perbedaan menyangkut penempatan dari Asas-asas Umum Pemerintahan yang Baik (AAUPB) sebagai dasar gugatan. AAUPB di Perancis lebih dikembangkan melalui yurisprudensi, sedangkan Indonesia hampir memiliki kesamaan dengan Belanda. AAUPB di Belanda semula dikembangkan melalui yurisprudensi, namun dalam perkembangannya AAUPB yang sering dipergunakan sebagai dasar pengujian beschikking dimasukkan sebagai materi muatan artikel 8 Wet AROB. Sekalipun demikian, substansi AAUPB dalam penjelasan Pasal 53 ayat (2) huruf b UU No. 9 Tahun 2004 kebanyakan berbeda dengan AAUPB yang dikembangkan di Perancis maupun di Belanda. AAUPB yang dikembangkan di Indonesia dengan merujuk UU No. 28 Tahun 1999 lebih banyak dipengaruhi oleh unsur-unsur good governance yang semula dipelopori oleh World Bank dan lebih memerlihatkan karakter ekonomi daripada memerlihatkan karakter hukum. Cukup banyak hasil penelitian 
yang menunjukkan bahwa yurisprudensi Peradilan TUN di Indonesia tetap mengembangkan AAUPB yang semula diperkenalkan melalui doktrin hukum administrasi negara baik di Perancis, Jerman, Belanda maupun Indonesia, sekalipun secara normatif tetap menggunakan "payung hukum" Pasal 53 ayat (2) UU No. 9 Tahun 2004.

Gambar 1

Struktur Organisasi Peradilan Tata Usaha Negara Indonesia

\begin{tabular}{|l|c|c|c|}
\hline \multicolumn{4}{|c|}{ Mahkamah Agung RI } \\
\hline Peradilan Umum & Peradilan Agama & Peradilan Militer & $\begin{array}{c}\text { Peradilan Tata } \\
\text { Usaha Negara }\end{array}$ \\
\hline
\end{tabular}

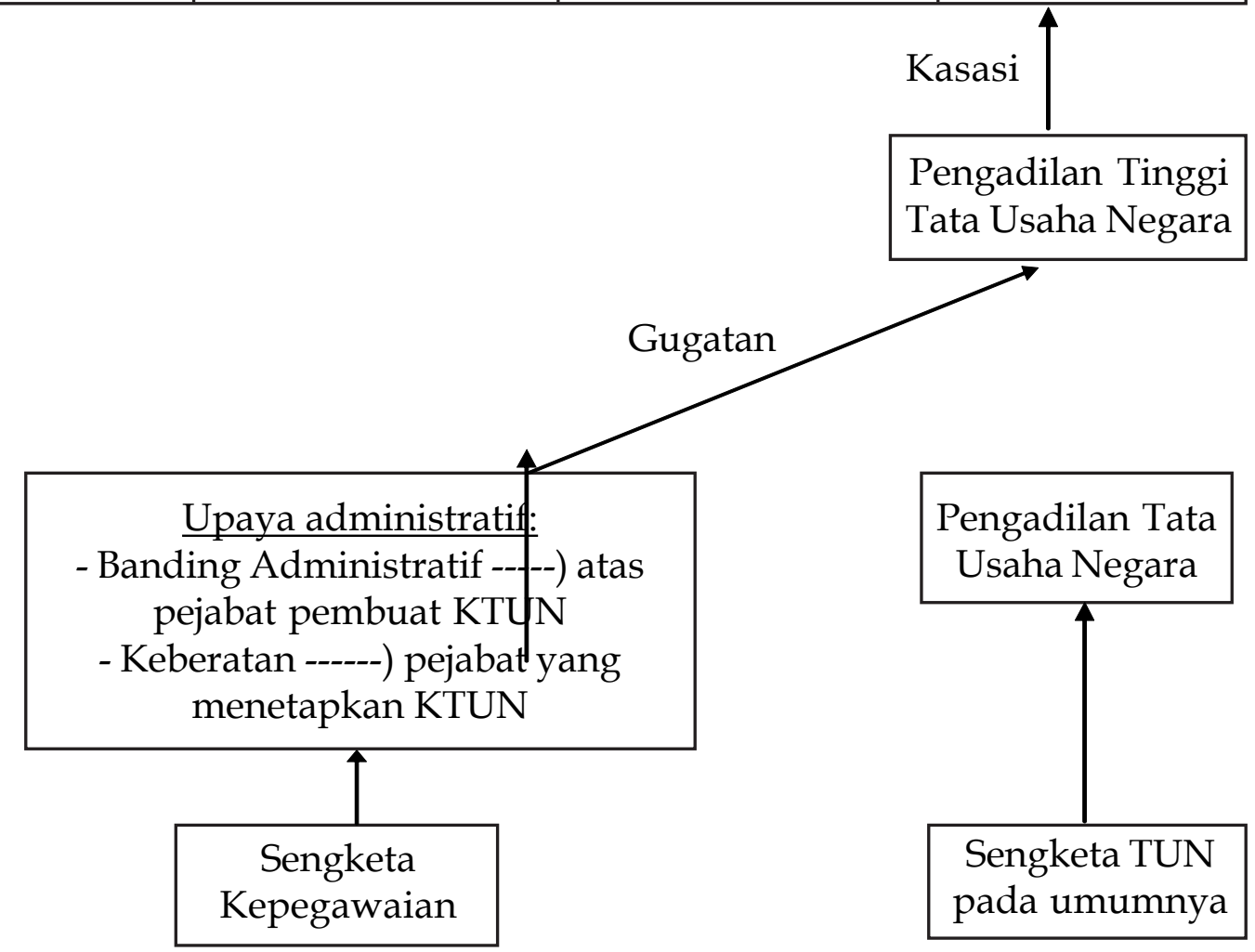

\section{Perbandingan Sistem Pengawasan Peradilan Tata Usaha Negara}

Keberadaan Peradilan Tata Usaha Negara sebagai suatu institusi yang mandiri dalam struktur kekuasaan kehakiman merupakan salah satu ciri dari negara hukum bertradisi Eropa Kontinental. Sistem Peradilan Tata Usaha Negara di Indonesia lebih mendekati sistem Peradilan Tata Usaha Negara di Perancis, sekalipun terdapat beberapa perbedaan. Pertama, sistem Peradilan Tata Usaha Negara di Perancis berpuncak di Conseil d'etat (semacam lembaga DPA), bukan di Cour de cassation (semacam lembaga MA di Indonesia). Kedua, di Perancis terdapat pengkhususan 
Peradilan Tata Usaha Negara yang menyelesaikan jenis sengketa-sengketa tata usaha negara tertentu sesuai dengan kompetensi khususnya. Sedangkan Peradilan Tata Usaha Negara di Indonesia bersistem umum yang menangani semua jenis sengketa tata usaha negara. Meskipun terdapat penyelesaian sengketa khusus kepegawaian, namun setelah melewati upaya admistratieve beroep dan pihak yang dikalahkan tidak bisa menerima putusan dari penyelesaian upaya administratif tersebut, dapat mengajukan gugatan ke Pengadilan Tinggi Tata Usaha Negara. Ketiga, Baik Conseil d'etat maupun Tribunal Administratif di Perancis memiliki fungsi pengawasan preventif (penasihatan) maupun represif (pengujian akta administratif). Peradilan Tata Usaha Negara di Indonesia fungsi pengawasannya hanya bersifat represif (pengujian atas Keputusan Tata Usaha Negara secara a posteriori).

Meskipun demikian, duality of jurisdiction dalam sistem Peradilan Tata Usaha Negara di Perancis yang membedakan sistem penyelesaian sengketa tata usaha negara dengan sistem penyelesaian sengketa perdata, memiliki kesamaan dengan sistem peradilan di Indonesia dan pada umumnya di negara-negara bertradisi hukum Eropa Kontinental. Sistem Peradilan Tata Usaha Negara di Perancis dan Indonesia memiliki kesamaan dalam dasar pengawasan terhadap tindakan hukum tata usaha negara, yaitu dasar pengawasan berdasarkan peraturan perundang-undangan yang bersifat tertulis (schriftelijke recht) dan asas-asas umum pemerintahan yang baik sebagai hukum tak tertulis (onschriftelijk recht). Dalam kedua sistem peradilan tata usaha negara baik di Indonesia maupun Perancis fungsi hakim dalam persidangan juga didasarkan atas Asas Keaktifan Hakim dan Asas Pembuktian Bebas. Hal itu disebabkan tujuan untuk mewujudkan kebenaran materiil dalam pengujian Keputusan Tata Usaha Negara yang pada umumnya menjadi karakter dari sistem Peradilan Tata Usaha Negara di negara-negara yang bertradisi hukum Eropa Kontinental.

Jika mencermati kedua sistem Peradilan Tata Usaha Negara di Perancis dan Indonesia terlihat bahwa dengan sifat aktif-pasif sistem Peradilan Tata Usaha Negara di Perancis melalui kewenangan penasihatan dan pengujian KTUN dari Conseil d'etat pengawasan terhadap pemerintah di Perancis memiliki karakter preventif dan represif. Fungsi penasihatan yang dilaksanakan oleh Conseil d'etat tersebut bisa mencegah terjadinya tindakan hukum tata usaha negara pemerintah di Perancis agar tidak melanggar peraturan perundang-undangan dan asas-asas umum pemerintahan yang baik. 
Pelaksanaan fungsi penasihatan tersebut sejauh dilaksanakan secara optimal dan dipatuhi oleh pejabat pemerintah di Perancis pada hakikatnya juga bisa meminimalisir terjadinya sengketa-sengketa tata usaha negara di kemudian hari asal pemerintah dalam mengeluarkan Keputusan Tata Usaha Negara (akta administratif) menggunakan referensi dan konsiderasi sebagaimana yang telah disarankan oleh Conseil d'etat. Jika dibandingkan dengan sistem ketatanegaraan Indonesia sebelum dilakukan amandemen atas UUD 1945, dapat dianalogikan dengan fungsi Dewan Pertimbangan Agung (DPA) yang secara teoretis juga memiliki atribusi fungsi penasihatan tersebut. Sengketa tata usaha negara yang terjadi sebagai gugatan dari warga masyarakat yang ditangani melalui pelaksanaan fungsi represif dari Conseil d'etat, hanya terjadi jika saran-saran yang sudah diberikan oleh Conseil d'etat dilanggar/diabaikan pejabat pemerintah atau ada Keputusan Tata Usaha Negara yang setelah ditetapkan ternyata melanggar hak-hak administratif warga masyarakat. Pola serupa sebenarnya bisa dipertimbangkan dengan mengatribusikan fungsi penasihatan terhadap Peradilan Tata Usaha Negara di Indonesia. Ide tersebut dapat menjadi bagian dari dinamika pelaksanaan fungsi Peradilan Tata Usaha Negara di Indonesia.

Penambahan atribusi wewenang penasihatan terhadap Peradilan Tata Usaha Negara dapat dilakukan melalui amandemen UU Peradilan Tata Usaha Negara dan UU Mahkamah Agung. Sebenarnya, jika dibandingkan dengan sistem relasi kekuasaan pemerintahan (dalam arti luas) di masa lalu juga sudah dikenal eksistensi forum Musyawarah Pimpinan Daerah (Muspida) di berbagai daerah yang bertujuan melakukan fungsi koordinasi antara para pejabat daerah dalam pelaksanaan kebijakan masing-masing di daerah tanpa bermaksud saling mengintervensi. Meski tentunya ada perbedaan yang mendasar antara fungsi penasihatan Conseil d'etat dengan forum Muspida tersebut, namun bisa menjadi inspirasi untuk mengelaborasi atribusi fungsi penasihatan dari Peradilan Tata Usaha Negara terhadap pemerintah seperti yang dikenal dalam sistem ketatanegaraan di Perancis. Fungsi penasihatan (advieserende functie) dari Peradilan Tata Usaha Negara di Indonesia bisa menjadi sarana untuk meningkatkan kualitas keputusan-keputusan tata usaha negara yang dikeluarkan pemerintah. Distribusi wewenang ketatanegaraan antarpenyelenggara kekuasaan negara tidak melarang adanya fungsi koordinasi maupun penasihatan antarpenyelenggara negara sejauh hal itu tidak mengarah pada terjadinya saling mengintervensi wewenang yang dimiliki oleh masing-masing penyelenggara negara. Bukankah jika pemerintah seringkali meminta fatwa kepada Mahkamah Agung bisa 
dimaknai sebagai semacam dimensi aktif fungsi yudikatif oleh Mahkamah Agung untuk memberikan pendapat hukum atas permintaan penyelenggara negara yang lain mengenai suatu masalah hukum yang dihadapi? Pemikiran untuk mengatribusikan fungsi penasihatan institusi Peradilan Tata Usaha Negara tersebut tentunya harus didasarkan atas kajian yang cermat untuk mencegah terjadinya "penyanderaan" lembaga Peradilan Tata Usaha Negara oleh pemerintah, jika suatu saat suatu Keputusan Tata Usaha Negara yang sudah dikeluarkan oleh pejabat tata usaha negara berdasarkan nasihat-nasihat Peradilan Tata Usaha Negara di kemudian hari digugat oleh warga masyarakat karena ternyata dalam pelaksanaannya dinilai melanggar hak-hak administratif dari warga masyarakat. Institusi Peradilan Tata Usaha Negara tetap memiliki ruang kebebasan sesuai dengan prinsip kebebasan hakim dalam kerangka kemandirian peradilan untuk menilai secara komprehensif legalitas Keputusan Tata Usaha Negara tersebut dikaitkan dengan sistem perlindungan hukum publik terhadap hak-hak warga masyarakat pencari keadilan. Tentu saja nasihat-nasihat yang sudah diberikan sebelum suatu Keputusan Tata Usaha Negara ditetapkan bisa tetap digunakan sebagai konsiderasi bagi Peradilan Tata Usaha Negara dalam menilai legalitas Keputusan Tata Usaha Negara tersebut.

\section{Penutup}

Keberadaan Peradilan Tata Usaha Negara sebagai suatu institusi yang mandiri dalam struktur kekuasaan kehakiman merupakan salah satu ciri dari negara hukum bertradisi Eropa Kontinental. Sistem Peradilan Tata Usaha Negara di Indonesia lebih mendekati sistem Peradilan Tata Usaha Negara di Perancis, sekalipun terdapat beberapa perbedaan.

Jika mencermati dua sistem Peradilan Tata Usaha Negara di Perancis dan Indonesia terlihat bahwa dengan sifat aktif-pasif sistem Peradilan Tata Usaha Negara di Perancis melalui kewenangan penasihatan dan pengujian KTUN dari Conseil d'etat pengawasan terhadap pemerintah di Perancis memiliki karakter preventif dan represif. Fungsi penasihatan yang dilaksanakan oleh Conseil d'etat tersebut bisa mencegah terjadinya tindakan hukum tata usaha negara pemerintah di Perancis agar tidak melanggar peraturan perundang-undangan dan asas-ass umum pemerintahan yang baik.

Pelaksanaan fungsi penasihatan tersebut sejauh dilaksanakan secara optimal dan dipatuhi oleh pejabat pemerintah di Perancis pada hakikatnya juga bisa 
meminimalisir terjadinya sengketa-sengketa tata usaha negara di kemudian hari asal pemerintah dalam mengeluarkan Keputusan Tata Usaha Negara (akta administratif) menggunakan referensi dan konsiderasi sebagaimana yang telah disarankan oleh Conseil d'etat. Pola serupa sebenarnya bisa dipertimbangkan untuk diberikan kepada Peradilan Tata Usaha Negara di Indonesia dengan mengatribusikan fungsi penasihatan terhadap Peradilan Tata Usaha Negara di Indonesia. Ide tersebut dapat menjadi bagian dari dinamika pelaksanaan fungsi Peradilan Tata Usaha Negara di Indonesia. Penambahan atribusi wewenang penasihatan terhadap Peradilan Tata Usaha Negara dapat dilakukan melalui amandemen UU Peradilan Tata Usaha Negara dan UU Mahkamah Agung. Fungsi penasihatan (advieserende functie) dari Peradilan Tata Usaha Negara di Indonesia bisa menjadi sarana untuk meningkatkan kualitas keputusan-keputusan tata usaha negara yang dikeluarkan pemerintah.

\section{Daftar Pustaka}

Brown, L Neville, et.al., French Administrative Law, Fifth Edition, Clarendon Press Oxford, UK, 1998.

Cruz, Peter de, Comparative Law in a Changing World, second edition, Cavendish Publishing Limited, Sidney, Australia, 1999.

Hadjon, PM., Fungsi Normatif Hukum Administrasi dalam Mewujudkan Pemerintahan yang Bersih, Pidato diucapkan dalam peresmian penerimaan jabatan Guru Besar dalam Ilmu Hukum pada Fakultas Hukum Universitas Airlangga pada hari Senin tanggal 10 Oktober 1994.

Ibrahim, Johnny, Teori dan Metodologi Penelitian Hukum Normatif, Bayumedia, Malang, 2006.

Lotulung, Paulus Effendie, Beberapa Sistem tentang Kontrol Segi Hukum terhadap Pemerintah (Edisi ke-II dengan revisi), Penerbit Citra Aditya Bakti, Bandung, 1993.

Marbun, Peradilan Administrasi Negara dan Upaya Adminstratif di Indonesia, Liberty, Yogyakarta, 1997.

Riawan Tjandra, W., Demokrasi Melawan Kekuasaan Melalui PTUN, Penerbitan Universitas Atma Jaya Yogyakart, 2009.

Teori dan Praktik Peradilan Tata Usaha Negara, Cahaya Atma Pustaka, Yogyakarta, 2011.

Sauveplanne, JG., Rechtsstelsels in Vogelvlucht-Een Inleiding tot de Privaatsrechtsvergelejiking, tweede druk, Kluwer - Deventer, 1981.

Seerden, Rene dan Frits Stroink, Administrative Law of the European Union, its Member States and the United States, Intersentia Uitgevers Antwerpen, Groningen Netherlands, 2002. 